Mycologia, 101(4), 2009, pp. 473-483. DOI: 10.3852/08-178

(C) 2009 by The Mycological Society of America, Lawrence, KS 66044-8897

\title{
Ectomycorrhizal fungal communities of oak savanna are distinct from forest communities
}

\author{
I.A. Dickie ${ }^{1}$ \\ Landcare Research, Box 40, Lincoln, \\ 7640 New Zealand \\ B.T.M. Dentinger ${ }^{2}$ \\ P.G. Avis ${ }^{3}$ \\ D.J. McLaughlin \\ Department of Plant Biology, University of Minnesota, \\ St Paul, Minnesota 55108 \\ P.B. Reich \\ Department of Forest Resources, University of \\ Minnesota, St Paul, Minnesota 55108
}

\begin{abstract}
Oak savanna is one of the most endangered ecosystems of North America, with less than $0.02 \%$ of its original area remaining. Here we test whether oak savanna supports a unique community of ectomycorrhizal fungi, a higher diversity of ectomycorrhizal fungi or a greater proportional abundance of ascomycete fungi compared with adjacent areas where the absence of fire has resulted in oak savanna conversion to oak forest. The overall fungal community was highly diverse and dominated by Cenococcum geophilum and other ascomycetes, Cortinarius, Russula, Lactarius and Thelephoraceae. Oak savanna mycorrhizal communities were distinct from oak forest communities both aboveground (sporocarp surveys) and belowground (RFLP identification of ectomycorrhizal root tips); however total diversity was not higher in oak savanna than oak forests and there was no evidence of a greater abundance of ascomycetes. Despite not having a higher local diversity than oak forests, the presence of a unique fungal community indicates that oak savanna plays an important role in maintaining regional ectomycorrhizal diversity.
\end{abstract}

Key words: Ascomycota, conservation, diversity, fire, habitat loss, mycorrhizal ecology

\section{INTRODUCTION}

Oak savanna once dominated large areas of North America, but less than $0.02 \%$ of its original area

\footnotetext{
Accepted for publication 19 February 2009.

${ }^{1}$ Corresponding author. Landcare Research, PO Box 40, Lincoln 7640, New Zealand. Tel: +64 3321 9646; Fax: +64 3321 9998. Email: dickiei@landcareresearch.co.nz

${ }^{2}$ Current address: Department of Ecology and Evolutionary Biology, University of Toronto, Toronto, Ontario, Canada M5S 3B2.

${ }^{3}$ Current address: Biology Department, Indiana University Northwest, Gary, Indiana 46408.
}

remains (Nuzzo 1985). The oak savanna landscape (areas with continuous herbaceous cover dominated by grass and with discontinuous tree coverage) is fire dependent; frequent fires prevent woody dominance and maintain an open park-like setting (Tester 1996, Peterson and Reich 2001). While most of the loss of oak savanna has been due to agricultural conversion, other large areas have been lost due to the suppression of fire. In the absence of fire oak savanna converts first to oak forests (here defined as closedcanopy oak-dominated forest) and eventually to more shade-tolerant tree species (Peterson and Reich 2001). The conversion of oak savanna to oak forest is accompanied by a number of changes in soil fertility (White 1983, Reich et al 2001, McGill et al 2007).

Although the loss of any habitat is of conservation concern, there is limited evidence of any negative effects of savanna conversion on particular taxonomic groups. A number of plant species, particularly shrubs and forbs, reach their peak abundances in savanna, but most of these also are present in prairie (Bray 1960). Individual plant functional groups tend to show lower or higher species richness in savannas than adjacent grasslands or forests but are not restricted to the savanna (Peterson and Reich 2001). Similar limited fidelity for savanna habitat has been found for birds and arthropods, for which savanna communities are a mixture of forest and grassland communities (Siemann et al 1997, Grundel and Pavlovic 2007).

The effect of savanna loss on fungal communities is unclear. Oak forests in general are dependent on and support a diverse community of ectomycorrhizal fungi (Walker et al 2005, Bergemann and Garbelotto 2006, Avis et al 2008), but whether any ectomycorrhizal fungal species specifically require oak savanna is unclear. Fire, the driving ecological force in the persistence of savanna, has a number of known effects on fungal communities. Severe wildfire can kill fungal ectomycorrhizal genets, reduce diversity (Bruns et al 2002) and result in an increased dominance by fungi with resistant propagules (Taylor and Bruns 1999) and facultatively mycorrhizal species capable of surviving as saprotrophs (Egger 1986). Fires in savanna however are typically low intensity; the stems of trees smaller than $5 \mathrm{~cm}$ diam are almost always killed but the individual almost always survives and resprouts while the stems of most larger trees 
generally survive. Similarly grasses quickly resprout from roots and crowns and soil heating is minimal over large areas. Further the three major ectomycorrhizal hosts in Minnesota oak savanna are Quercus macrocarpa, Q. ellipsoidalis and Corylus americana, all three of which are also present in oak forests, while the one host plant that does decline with fire suppression, Helianthemum bicknelii, is relatively rare and appears to support largely the same fungal community as Quercus (Tester 1996, Dickie et al 2004). Oak savannas are highly spatially heterogeneous, creating a potentially greater number of spatial niches for fungi that preferentially occur distant from trees (Last et al 1984, Dickie and Reich 2005); this might be expected to increase fungal diversity in savanna. On the other hand oak savannas harbor fewer trees (i.e. smaller islands of habitat) compared with forests and because ectomycorrhizal species richness is known to relate to the size of habitat (Peay et al 2007) this might be expected to result in fewer species in savanna than in forest.

Higher level taxonomic groups might also be expected to occur preferentially in oak savanna. One fungal group that might be particularly expected preferentially to occur in oak savannas is the ectomycorrhizal ascomycetes (Tedersoo et al 2006). In extreme pinyon pine scrub ascomycetes are abundant (Gehring et al 1998), perhaps suggesting a higher abundance in savanna, which also can be more extreme than oak forests. We also have found ascomycetes to be more common on seedlings planted in abandoned agricultural fields than in adjacent oak forests (Dickie and Reich 2005), which suggests they might prefer open, disturbed habitat. Warcup (1991) found that ascomycetes dominated ectomycorrhizal communities on Eucalyptus after fire and Fujimura et al (2005) showed 15\% of ectomycorrhiza on roots of Pinus ponderosa in a postfire site were ascomycetes but in neither case was a direct comparison made with sites without fire. Ectomycorrhizal ascomycetes may be facultatively saprotrophic, permitting survival in the absence of host roots (Egger 1986). Increased soil $\mathrm{pH}$ in savanna might also favor ascomycetes because it has been suggested that higher soil $\mathrm{pH}$ favors sporocarp production of the ascomycetous genus Tuber (Hall et al 2008).

We studied the belowground and aboveground fungal community at the Cedar Creek Science Ecosystem Reserve, where prescribed burning has been performed for more than $30 \mathrm{y}$ to maintain oak savanna. We tested three hypotheses: (i) oak savanna and oak forests would support distinct communities of ectomycorrhizal fungi; (ii) the diversity of ectomycorrhizal fungi would be greater in oak savanna than in oak forest; and (iii) ascomycete ectomycorrhizal fungi would comprise a greater proportion of ectomycorrhizal fungi in oak savanna compared with oak forest.

\section{MATERIALS AND METHODS}

We used a combined belowground and aboveground sampling of fungal structures. Sampling ectomycorrhizal roots belowground, with a combined morphotyping and RFLP approach, let us detect species such as hypogeous ascomycetes that were not detectable aboveground (Smith et al 2007). Including aboveground sporocarp collections let us build a species list based on robust identifications with sporocarp vouchers, and permitted a much greater total area to be sampled.

Sites.-Cedar Creek Science Ecosystem Reserve and Long Term Ecological Research site in Minnesota, including burn history, has been described by Tester (1996) and Reich et al (2001). We sampled ectomycorrhizal fungi from six sites, three of which have had frequent controlled burns (plots $103,104,106)$, which we will refer to as savanna, and three of which have had no fire history during that period (plots $109,110,309)$, which we will refer to as forests. The sites differed markedly in soil parameters, including $\mathrm{pH}$ and nitrogen availability (TABLE I), both of which are likely to influence fungal communities (Lilleskov et al 2002, Avis et al 2008). A portion of plot 106 had been included in a nutrient addition experiment; we avoided this portion of the plot in belowground sampling (TABLE II).

Belowground sampling.-We sampled ectomycorrhizal fungi from individual roots collected in soil cores $2.8 \mathrm{~cm}$ diam and $20 \mathrm{~cm}$ deep. A common approach to sampling ectomycorrhizal communities is to use tree-centered soil cores (Gehring et al 1998, Avis et al 2003). This technique would be inappropriate for our sites because distance from trees is an important factor structuring fungal communities (Dickie and Reich 2005) and savanna sites have a highly heterogeneous spatial pattern of tree occurrence. We therefore established six, parallel, $100 \mathrm{~m}$ transects spaced $10 \mathrm{~m}$ apart in each plot, with 20 sampling points identified by flags every $5 \mathrm{~m}$ along these transects, and sampled cores randomly from these 120 points (80 in plot 106) until a minimum of 30 cores were obtained that contained ectomycorrhizal roots. In forests $100 \%$ of cores taken contained ectomycorrhizal roots; the final sample size was 31-32 cores (TABLE II). In savanna $61 \%$ of cores contained ectomycorrhizal roots, requiring 40-64 cores to obtain the desired sample size of a minimum of 30 cores with roots; the final sample size was 30-33 cores (TABLE II). Sampling was spread over 3 y (2002-2004), with sampling conducted in August each year and approximately 10 samples with roots per plot processed each year.

From each core we examined all root tips and sampled all unique morphological types, using PCR with ITS1F and ITS4 primers and RFLP to identify species. In comparing diversity estimates it is important to have equal sampling effort (Taylor 2002). For this study we equalized our sampling at the level of soil cores with ectomycorrhizal roots, sampling until approx- 
TABLE I. Site characters of research plots (data from Reich et al 2001)

\begin{tabular}{lcccc}
\hline \hline Plot number & $\begin{array}{c}\text { Burn frequency (burns/ } \\
\text { years) }\end{array}$ & $\begin{array}{c}\text { Basal area } \\
\left(\mathrm{m}^{2} \mathrm{ha}^{-1}\right)\end{array}$ & Soil $\mathrm{pH}$ & $\begin{array}{c}\text { Nitrogen availability } \\
\left(\mathrm{g} \mathrm{m}^{-2} \mathrm{yr}^{-1}\right)\end{array}$ \\
\hline 103 & $9 / 10$ & 12.4 & 5.8 & 3.0 \\
104 & $9 / 10$ & 7.8 & 5.7 & 1.9 \\
106 & $2 / 3$ & 17.4 & 5.5 & 4.2 \\
109 & 0 & 15.5 & 4.8 & 10.9 \\
110 & 0 & 19.3 & 4.6 & 15.7 \\
\\
\hline 09 & 0 & 28.3 & 4.1 & 15.9 \\
\hline
\end{tabular}

${ }^{\text {a }}$ Basal area is for tree-dominated areas within sites.

imately the same number of cores with ectomycorrhizal roots were obtained from each site and identifying all morphological species within those cores. An alternative approach would have been to treat individual root tips as the basis for equalizing sampling effort, counting the number of root tips of each unique morphological type and using rarefaction analysis to subsample equal numbers of root tips from all samples (Taylor 2002). We opted against this alternative for two reasons. First, treating individual root tips as independent sampling units assumes that each individual root tip in a soil core represents a fungal individual, which is clearly incorrect (Taylor 2002). Second, by sampling all morphological types within a set volume of soil, our results can be scaled on the same basis as sporocarp measurements, which are on a set area basis, or compared to studies of other taxonomic groups, which are almost universally taken on a set area or set volume basis. Nonetheless it is worth noting that sampling equal numbers of root tips would have increased the relative diversity of savanna samples, which had lower root densities compared to woodland samples (Taylor 2002).

Individual root tips were frozen in liquid $\mathrm{N}$, lyophilized and stored at $-20 \mathrm{C}$ until DNA analysis. DNA was extracted and amplified following the kit-based protocol of Avis et al (2003). RFLP patterns were obtained with HinfI and DpnII enzymes (NEB, Beverly, Massachusetts), run in $2 \%$ agarose gels, with RFLP patterns matched with the GERM (good-enough RFLP matcher) spreadsheet program (Dickie et al 2003). Our overall success rate for PCR amplification was $64 \%$ of total

TABLE II. Species diversity in sporocarp collections and on root tips by plot and fire frequency (plot 106 not included for sporocarps due to unequal sampling)

\begin{tabular}{|c|c|c|c|c|c|}
\hline Plot & $\mathrm{n}$ & Species & $\mathrm{Chao}^{\mathrm{a}}$ & Jackknife $^{\mathrm{b}}$ & $\mathrm{H}^{\prime c}$ \\
\hline \multicolumn{6}{|l|}{ Sporocarps } \\
\hline 103 & 120 & 25 & $53.1(20.9)$ & 50.0 & 2.8 \\
\hline 104 & 120 & 37 & $49(9.2)$ & 54.7 & 2.1 \\
\hline Burned & 240 & 46 & $66.6(13.5)$ & 72.7 & 2.3 \\
\hline 109 & 120 & 40 & $52.8(8.4)$ & 61.8 & 2.5 \\
\hline 110 & 120 & 60 & $86.9(15.4)$ & 94.7 & 2.8 \\
\hline 309 & 120 & 31 & $87.3(49.8)$ & 58.6 & 2.2 \\
\hline Unburned & 360 & 72 & $105.3(21.0)$ & 105.9 & 2.8 \\
\hline All & 600 & 88 & $117(16.6)$ & 124.9 & 3.1 \\
\hline \multicolumn{6}{|l|}{ Root tips } \\
\hline 103 & 33 & 33 & $51.1(10.9)$ & 60.2 & 2.8 \\
\hline 104 & 30 & 31 & $79.4(30.7)$ & 68.3 & 2.9 \\
\hline 106 & 33 & 37 & $67.3(17.6)$ & 71.7 & 3.0 \\
\hline Burned & 96 & 67 & $97.0(14.2)$ & 112.5 & 3.3 \\
\hline 109 & 31 & 43 & $75.0(17.8)$ & 80.5 & 3.3 \\
\hline 110 & 32 & 61 & $127.7(29.7)$ & 126.4 & 3.6 \\
\hline 309 & 32 & 35 & $101.1(43.8)$ & 75.2 & 3.1 \\
\hline Unburned & 95 & 92 & $134(17.1)$ & 154.3 & 3.7 \\
\hline All & 191 & 123 & $160.1(14.0)$ & 187.7 & 3.8 \\
\hline
\end{tabular}

${ }^{a}$ Chao estimator of total species richness and standard error.

${ }^{\mathrm{b}}$ Second-order jackknife estimator of total species richness.

${ }^{c}$ Shannon diversity.

$\mathrm{n}$, number of sample points (sporocarps) or cores (mycorrhizal root tips). 
reactions producing sufficient product for visualization. Of the $64 \%$ of samples producing PCR products, $13 \%$ had multiple bands and were therefore not analyzed with RFLP.

Sporocarp sampling.-For aboveground data we sampled $4 \mathrm{~m}^{2}$ circles around the same 120 points established for belowground sampling, totaling $480 \mathrm{~m}^{2}$ of area sampled per plot (1440 $\mathrm{m}^{2}$ for each forest type). The total area sampled for each forest type falls within the suggested minimum of 1000-1600 $\mathrm{m}^{2}$ required to evaluate species diversity and abundance (Bills et al 1986). Plots were visited every 7-10 d or more or less frequently according to patterns of precipitation, late Jun through mid-Oct 1998, 1999 and 2002. At each sample point we recorded the species identity and number of sporocarps for groups of taxa containing probable ectomycorrhizal species within each $4 \mathrm{~m}^{2}$. Collections were made when the identity of the taxon could not be verified in the field. Each species recorded from the plots is represented by at least one voucher collection deposited at the University of Minnesota Herbarium. Ectomycorrhizal taxa outside the sample points also were recorded or collected to completely document species diversity in the plots, but these were not included in our analysis.

At five of our six sites (forests 109, 110 and 309 and savannas 103 and 104) we collected sporocarp data based on the plot design described above. At the sixth site (savanna 106) sporocarp collections were available from only three collection events from 80 sample points instead of 120 as at other sites; however we were able to supplement the species lists from collections by Avis et al (2003) that were immediately adjacent to the belowground sampling plot. Avis et al (2003) included fertilized plots, but we included supplementary collection information from unfertilized plots only.

Statistics._For belowground collections we considered all occurrences of a species within a soil core as a single occurrence. Replication (three replicates of each site type) was insufficient to determine whether any particular species showed a habitat preference. We therefore developed a Monte Carlo model to test whether overall more species were exclusive to savanna or forest than would be expected based on random chance. We considered only the numbers of species that were both exclusive to a site type and occurred in all three replicates of that site type. We then approximated the probability of this number of "exclusive", species arising by chance given the total number of species found in exactly three sites by rerandomizing species occurrences 100000 times with both equal and speciesrichness-adjusted probabilities of occurrences. This method assumes that species occurrences are independent (i.e. that the presence of one fungal species does not determine whether a second species is present or absent). All statistics were carried out in R ( $\mathrm{R}$ Development Core Team 2008) with estimates of species richness calculated with the package vegan (Oksanen et al 2008).

\section{RESULTS}

Belowground sampling.-From 191 soil cores with ectomycorrhizal roots a total of 123 RFLP types were detected belowground (FIG. 1), of which 48 were found only once and 31 only twice. We identified 42 of the 123 types, including all but one of the species found more than five times; in total we identified $73 \%$ of RFLP pattern occurrences. Three RFLP patterns matching Cenococcum geophilum were treated as independent "species"; of these one pattern ( $C$. geophilum A) accounted for $93 \%$ of C. geophilum collections. Species found in 10 or more soil cores were C. geophilum A, Cortinarius sp 4 (matching C. cf. iliopodius), Russula aff. seperina, Lactarius sp 1 (matching L. camphoratus), Russula aff. amoenolens, Pezizales sp 1 (matching Humaria hemisphaerica) and Genea sp 1 (matching G. hispidula, TABLE III). Of the 42 identified species, seven were ascomycetes (182 occurrences), 15 were Russulaceae (123 occurrences), six were Cortinariaceae (45 occurrences), four were Amanitaceae (all Amanita spp., 10 occurrences), three were Thelephoraceae (16 occurrences), with the remaining families having only two (Atheliaceae, Sebacinaceae) or one (Boletaceae, Leotiaceae, Tricholomataceae) species found belowground. The estimates of total richness were $160 \pm 14$ (Chao1 \pm SE) and 188 RFLP species (second-order jackknife).

Sixteen species occurred belowground in exactly three sites; of these five were exclusive to either savanna or forest. Two species occurred exclusively in all three savannas, Pezizales 2 (matching Hydnotrya tulasnei) and IDMT00825. Three species occurred exclusively in all three forests, Piloderma sp 1 (matching $P$. lanatum), IDMT00280a and Pezizales sp 1. The probability of this level of exclusivity (five out of 16 ) occurring by chance is $P=0.017 \%$ or $P=$ $0.020 \%$ based on 100000 randomizations of species with equal and species-richness-adjusted probabilities of species occurrences respectively.

There was no evidence of higher diversity in burned than unburned plots from belowground data. Estimated species richness (Chao, second-order jackknife) and Shannon Diversity $\left(\mathrm{H}^{\prime}\right)$ were generally higher in forests than savannas (TABLE I). The rate of species accumulation with sampling effort for savannas also was lower for savannas than for forests (FIG. 1).

Two families, the Russulaceae and Thelephoraceae, were more frequent in forests than savannas $(P=$ 0.036 and $P=0.044$ respectively). The frequency of ascomycetes was not significantly affected by site type, regardless of whether Cenococcum geophilum was included.

Sporocarp collections. - A total of 3631 individual sporocarps were observed, representing 110 identified taxa (TABLE IV). In the forest plots the most frequently encountered taxa throughout the warmer 


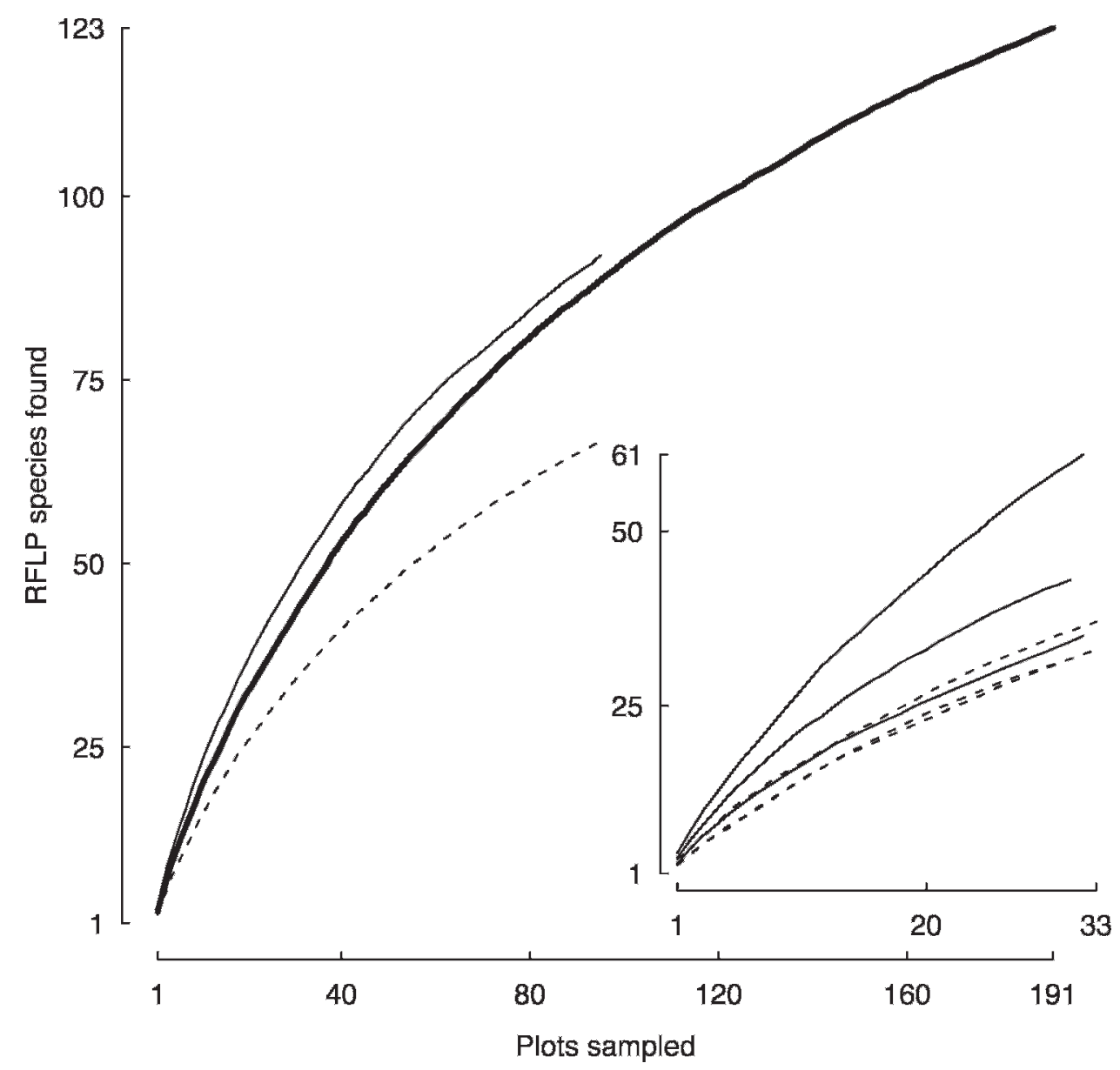

FIG. 1. Belowground sampling effort curve for all sites (thick line), all forests (thin line) and savannas (dashed line); curves for individual plots inset (forests as thin lines, savannas as dashed lines).

months were Russulaceae (especially Lactarius camphoratus, Russula seperina and other Russula spp.), Cortinariaceae (Cortinarius subgen. Telamonia), Amanitaceae (especially Amanita sect. Vaginatae), Laccaria spp. and Tremellodendron pallidum, whereas Tricholoma spp. became the most abundant in the later, cooler months. Sporocarp records in savanna plots were made almost exclusively after recent rains whereas sporocarps were recorded in forest plots on most visits, although sporocarp abundance was largely dependent on recent rains. There was substantial interannual variation in sporocarp numbers in forest plots (178 min, 813 max, sum across all plots) with lower numbers but also less inter-annual variability in savannas (150 min to 208 max across all plots). Sporocarps in savanna plots were rarely recorded distant from trees, creating a noticeable clumping effect not observed in the forest plots.

The lowest diversity encountered was in savanna plot 103, with 25 fungal species collected (estimated total 50-53 species), with the highest diversity in forest plot 110 with 60 fungal taxa (estimated total
87-95 species, TABLE II). There was no evidence that diversity was higher in savanna than forests.

Fourteen species occurred as sporocarps in exactly three sites; of these six were exclusive to either savanna or forest. Two species occurred exclusively in all three savannas, Boletus nobilissimus and Russula brevipes. Four species occurred exclusively in all three forests, Amanita brunnescens, Laccaria amethystina, L. ochropurpurea and Lactarius subserifluus (TABLE IV). This level of exclusivity ( six or more of 14 species) was observed in $0.0014 \%$ and $0.0011 \%$ of 100000 randomizations of species with equal and speciesrichness-adjusted probabilities of species occurrences respectively.

\section{DISCUSSION}

The community was broadly similar to those described for Quercus-associated ectomycorrhizal fungi elsewhere, with a relatively high dominance by ascomycetes (Cenococcum, Pezizales, Genea), Cortinarius, Russula, Lactarius and Thelephoraceae and a 
TABLE III. Collection numbers of RFLP species by site for all species collected at least three times, including GenBank accession numbers for sequence based identifications and best matching named sequence in GenBank

\begin{tabular}{|c|c|c|c|c|c|c|c|c|c|}
\hline \multirow[b]{2}{*}{ Species } & \multicolumn{3}{|c|}{ Savannas } & \multicolumn{3}{|c|}{ Forests } & \multirow[b]{2}{*}{ Total } & \multirow[b]{2}{*}{ Accession } & \multirow[b]{2}{*}{ Basis for identity ${ }^{a}$} \\
\hline & 103 & 104 & 106 & 109 & 110 & 309 & & & \\
\hline Cenococcum geophilum A & 27 & 20 & 27 & 23 & 26 & 17 & 140 & - & RFLP match to sclerotia \\
\hline Cortinarius sp 4 & 7 & 3 & 5 & 7 & 6 & 5 & 33 & EU880222 & AJ889948.1 Cortinarius cf. iliopodius; 584/607 \\
\hline Russula aff. seperina & 2 & 1 & 6 & 7 & 6 & 8 & 30 & - & RFLP match to sporocarp djm1099 \\
\hline Lactarius $\operatorname{sp} 1$ & 1 & 2 & 7 & 4 & 4 & 1 & 19 & EU880219 & AJ889960.1 Lactarius camphoratus; 686/723 \\
\hline Russula aff. amoenolens & 1 & 4 & 2 & 1 & 0 & 6 & 14 & - & RFLP match to sporocarp djm1192 \\
\hline Pezizales sp 1 & 0 & 0 & 0 & 2 & 5 & 4 & 11 & FJ147328 & DQ200832.1 Humaria hemisphaerica; 693/699 \\
\hline Genea $\operatorname{sp} 1$ & 0 & 1 & 2 & 2 & 1 & 4 & 10 & EU880217 & AJ969622.2 Genea hispidula; 629/634 \\
\hline $\begin{array}{l}\text { Russula aff. } \\
\text { pectinatoides }\end{array}$ & 2 & 3 & 0 & 0 & 1 & 3 & 9 & AY640411 & EU598185.1 Russula pectinatoides 624/625 \\
\hline Thelephoraceae sp 1 & 1 & 0 & 1 & 4 & 1 & 1 & 8 & EU880218 & $\begin{array}{l}\text { DQ150117.1 Uncultured Thelephoraceae; } \\
632 / 661\end{array}$ \\
\hline Russula sp 2 & 0 & 1 & 2 & 2 & 2 & 1 & 8 & EU880215 & DQ777996.1 Russula sp; 659/665 \\
\hline Pezizalean I & 2 & 2 & 2 & 1 & 0 & 0 & 7 & EU588985 & EU427549.1 Pachyphloeus sp; 302/354 \\
\hline Cortinarius violaceus & 1 & 0 & 1 & 3 & 2 & 0 & 7 & - & RFLP match to sporocarp kh137 \\
\hline Russulaceae sp 3 & 1 & 1 & 1 & 0 & 0 & 4 & 7 & EU880224 & AY239349.1 Gymnomyces fallax; 673/691 \\
\hline Lactarius maculatipes & 1 & 1 & 0 & 2 & 1 & 1 & 6 & - & RFLP match to sporocarp djm 1208 \\
\hline Russula $\mathrm{sp} 4$ & 0 & 0 & 2 & 2 & 1 & 1 & 6 & - & RFLP match to sporocarp kh91 \\
\hline PAMT332 & 1 & 0 & 0 & 0 & 4 & 1 & 6 & - & $=$ MT846-2000-RFLP36 in Avis et al (2003) \\
\hline Cenococcum geophilum $\mathrm{B}$ & 1 & 1 & 3 & 0 & 0 & 1 & 6 & - & RFLP match to morphotype with stellate mantle \\
\hline IDMT00114a & 1 & 0 & 3 & 1 & 0 & 0 & 5 & - & (unknown) \\
\hline Piloderma sp 1 & 0 & 0 & 0 & 2 & 1 & 2 & 5 & EU880221 & DQ469288.1 Piloderma lanatum; 625/634 \\
\hline IDMT00307 & 0 & 0 & 1 & 1 & 3 & 0 & 5 & - & (unknown) \\
\hline IDMT00834 & 3 & 0 & 0 & 1 & 1 & 0 & 5 & - & (unknown) \\
\hline IDMT01806 & 0 & 0 & 2 & 0 & 1 & 2 & 5 & - & (unknown) \\
\hline Russula sp 5 & 0 & 0 & 2 & 3 & 0 & 0 & 5 & EU880216 & AY750164.1 Russula sp; 665/684 \\
\hline Amanita cf. fulva & 0 & 0 & 3 & 0 & 2 & 0 & 5 & - & RFLP match to sporocarp kh27 \\
\hline Lactarius camphoratus & 0 & 0 & 0 & 4 & 0 & 1 & 5 & - & RFLP match to sporocarp kh61 \\
\hline Tomentella cf. bryophila & 2 & 0 & 0 & 1 & 2 & 0 & 5 & - & RFLP match to sporocarp PA380 \\
\hline Byssocorticium sp 1 & 0 & 0 & 1 & 3 & 0 & 1 & 5 & EU880220 & AJ889936.1 Byssocorticium atrovirens; $610 / 624$ \\
\hline IDMT00280a & 0 & 0 & 0 & 2 & 1 & 1 & 4 & - & (unknown) \\
\hline Pezizales sp 2 & 1 & 2 & 1 & 0 & 0 & 0 & 4 & EU880227 & AJ969621.1 Hydnotrya tulasnei; 702/746 \\
\hline Russula $\operatorname{sp} 6$ & 3 & 0 & 1 & 0 & 0 & 0 & 4 & EU880225 & AF418639.1 Russula sp; 651/668 \\
\hline Sebacinoid "RFLP 4", & 0 & 0 & 0 & 0 & 4 & 0 & 4 & - & $=$ "RFLP 4" in Avis et al (2003) \\
\hline Cenococcum geophilum $\mathrm{C}$ & 2 & 0 & 0 & 0 & 1 & 1 & 4 & - & RFLP match to morphotype with stellate mantle \\
\hline Amanita pantherina & 1 & 2 & 0 & 0 & 0 & 0 & 3 & - & $\begin{array}{l}\text { RFLP match to sporocarp djm1151 }(A . \\
\text { pantherina var. multisquamosa) }\end{array}$ \\
\hline Thelephora terrestris & 0 & 0 & 0 & 0 & 1 & 2 & 3 & - & RFLP match to sporocarp djm1152 \\
\hline IDMT00106a & 0 & 0 & 0 & 2 & 0 & 1 & 3 & - & (unknown) \\
\hline IDMT00305a & 0 & 0 & 0 & 3 & 0 & 0 & 3 & - & (unknown) \\
\hline IDMT00307 & 1 & 0 & 0 & 1 & 1 & 0 & 3 & - & (unknown) \\
\hline IDMT00651a & 0 & 0 & 0 & 0 & 3 & 0 & 3 & - & (unknown) \\
\hline IDMT00825 & 1 & 1 & 1 & 0 & 0 & 0 & 3 & - & (unknown) \\
\hline Sebacinaceae $\mathrm{sp} 1$ & 0 & 0 & 1 & 1 & 1 & 0 & 3 & EU880223 & EF372401.1 Sebacinaceae sp; 537/622 \\
\hline IDMT01852 & 2 & 0 & 1 & 0 & 0 & 0 & 3 & - & (unknown) \\
\hline IDMT02360 & 1 & 0 & 0 & 1 & 1 & 0 & 3 & - & (unknown) \\
\hline Russula $\mathrm{sp} 7$ & 2 & 1 & 0 & 0 & 0 & 0 & 3 & EU880225 & DQ422015 Russula cf. maculata; 608/673 \\
\hline Russula silvicola & 0 & 0 & 0 & 1 & 2 & 0 & 3 & - & RFLP match to sporocarp kh83 \\
\hline
\end{tabular}

\footnotetext{
${ }^{\text {a }}$ Species were identified by RFLP matching to sporocarps. For any species found more than five times that failed to match a sporocarp we attempted sequence identification; the best matching named species in GenBank is noted with accession number, species name and matching base pairs.
} 
high level of diversity (Valentine et al 2004, Richard et al 2005, Gebhardt et al 2007, Smith et al 2007).

Community differences.-Our first hypothesis, that oak savanna and oak forests would support distinct communities of ectomycorrhizal fungi, was supported. The analysis of ectomycorrhizal communities has been problematic in studies where the treatment of interest is at a large scale (e.g. stand, plot). The high diversity of ectomycorrhizal fungal communities has meant that the characterization of each replicate comes at a high cost in time and resources; hence replication has been severely limited (e.g. three replicates of two treatments in this study). In this study we have used a novel statistical approach to attempt to surmount the difficulty of low replication of diverse communities. Looking only at the subset of species with exactly three occurrences, we observed a much higher degree of "exclusivity" to one of the two plot types than would have been expected by random chance. Although this indicates that the two communities are different, this approach cannot indicate which particular species drive this difference. Thus we can draw a community-level conclusion (the communities are different) but cannot use the result to infer anything about species level properties.

Although sporocarp and belowground data revealed different communities, both datasets showed evidence of greater than expected species exclusivity to savanna or forests. The results were somewhat more significant for sporocarps $(P=0.0014)$ than for belowground data $(P=0.017)$. In part this might reflect the greater sample size and better taxonomic resolution of aboveground sporocarp surveys than is possible belowground (Lilleskov et al 2002). It is also possible that sporocarp production is a more sensitive indicator of species responses than belowground presence. Sporocarp and belowground fungal communities are often only loosely correlated, with many species present belowground not forming sporocarps (Dahlberg et al 1997, Zhou and Hogetsu 2002). Sporocarp production requires a significant ability to capture resources (Dahlberg et al 1997, Zhou and Hogetsu 2002); this might make sporocarp production a more sensitive measure of habitat preference and environmental impact than belowground surveys.

Species diversity.-Our second hypothesis, that the diversity of ectomycorrhizal fungi would be greater in oak savanna than in oak forest, was not supported; if anything the opposite pattern appears to be true. We had expected higher diversity based on oak savanna being the more "natural" habitat for the area and the greater spatial heterogeneity of trees creating more fungal niches in terms of distance from trees (Dickie and Reich 2005). Our failure to find higher fungal diversity in oak savanna might reflect a loss of soil horizon complexity because fire removes organic horizons (Dickie et al 2002, Genney et al 2006) and woody debris (Tedersoo et al 2008), which are important ectomycorrhizal fungal niches. Further the reduction in tree density in oak savannas might represent a loss of effective habitat area, which might reduce fungal diversity (Peay et al 2007).

Ascomycete abundance.-Our third hypothesis, that ascomycete ectomycorrhizal fungi would be favored in oak savanna over basidiomycete ectomycorrhizal fungi, was not supported. We found no evidence of increased ascomycete abundance in savannas. Further, while Pezizales sp 2 was exclusively found in savanna, Pezizales sp 1 was found only in forests. Thus, while some studies have suggested that some Pezizaceae might be favored in openings and high stress sites (Dickie and Reich 2005, Smith et al 2006), our results suggest that this result cannot be generalized at the family level. This is consistent with the suggestion of Tedersoo et al (2006) that, while a number of ascomycete species appear to specialize on early successional and disturbed habitats, other ascomycete species are important components of mature forests. It is also possible that the frequent, low-intensity fire of oak savanna has less of an effect on ascomycete abundance than higher-intensity fires in pine or spruce ecosystems because Vrålstad et al (1998) found that ascomycetes increased in abundance only in areas with severe fire and not in areas where fire was less intense.

Ascomycetes in general were important components of the fungal community, with an overwhelming abundance of Cenococcum geophilum (140 occurrences compared with 33 occurrences for the second most abundant species belowground), as well as Pezizales sp 1, Genea sp 1 and Pezizalean I (TABLE III). The particularly high dominance of Cenococcum geophilum in the present study (and many others) might be partially an artifact of presorting root tips by morphotypes; highly distinct morphotypes such as C. geophilum (black) or Byssocorticium (bright blue) are less likely to be inadvertently omitted than less conspicuous morphotypes. Bulked root sampling (e.g. Smith et al 2007) might avoid this bias. On the other hand our sampling of single root tips reduces the potential for PCR biases to influence results. On the whole our results suggest that Ascomycetes are an important component of Quercus-associated ectomycorrhizal communities and that the ecology of this group of fungi remains largely unclear.

Importance of savanna in species conservation.-Boletus nobilissimus Both \& Riedel was found in all three savanna plots but not in forest plots. This commer- 
TABLE IV. Sporocarp collections (presence/absence) by site

\begin{tabular}{|c|c|c|c|c|c|c|c|}
\hline \multirow[b]{2}{*}{ Species } & \multicolumn{3}{|c|}{ Savannas } & \multicolumn{3}{|c|}{ Forests } & \multirow{2}{*}{$\begin{array}{c}\text { Number of } \\
\text { sites }\end{array}$} \\
\hline & 103 & 104 & 106 & 109 & 110 & 309 & \\
\hline Amanita bisporigera & 0 & 0 & 1 & 0 & 0 & 0 & 1 \\
\hline Amanita brunnescens & 0 & 0 & 0 & 1 & 1 & 1 & 3 \\
\hline Amanita $\mathrm{cf}$. porphyria & 0 & 1 & 0 & 0 & 0 & 0 & 1 \\
\hline Amanita cf. spreta & 0 & 1 & 1 & 0 & 0 & 0 & 2 \\
\hline Amanita citrina & 0 & 1 & 0 & 1 & 1 & 1 & 4 \\
\hline Amanita constricta & 0 & 1 & 0 & 0 & 0 & 0 & 1 \\
\hline Amanita flavoconia & 0 & 1 & 1 & 1 & 1 & 1 & 5 \\
\hline Amanita flavorubescens & 0 & 1 & 1 & 0 & 1 & 0 & 3 \\
\hline Amanita fulva & 0 & 0 & 0 & 0 & 1 & 1 & 2 \\
\hline Amanita gemmata & 0 & 1 & 0 & 0 & 0 & 0 & 1 \\
\hline Amanita muscaria var. alba & 1 & 1 & 0 & 0 & 0 & 0 & 2 \\
\hline Amanita pantherina & 0 & 1 & 1 & 0 & 0 & 0 & 2 \\
\hline Amanita peckiana & 0 & 1 & 0 & 0 & 1 & 0 & 2 \\
\hline Amanita rubescens & 0 & 1 & 1 & 0 & 1 & 0 & 3 \\
\hline Amanita sect. lepidella & 0 & 1 & 0 & 0 & 0 & 0 & 1 \\
\hline Amanita sect. mappae & 0 & 0 & 0 & 1 & 1 & 0 & 2 \\
\hline Amanita sp 1 & 0 & 1 & 0 & 1 & 1 & 0 & 3 \\
\hline Amanita sp 9 & 0 & 0 & 1 & 0 & 0 & 0 & 1 \\
\hline Amanita vaginata & 0 & 1 & 1 & 1 & 1 & 1 & 5 \\
\hline Amanita verna/virosa/bisporigera & 1 & 1 & 1 & 1 & 1 & 0 & 5 \\
\hline Boletus bicolor & 0 & 0 & 1 & 0 & 0 & 0 & 1 \\
\hline Boletus fraternus & 0 & 0 & 0 & 0 & 1 & 0 & 1 \\
\hline Boletus nobilissimus & 1 & 1 & 1 & 0 & 0 & 0 & 3 \\
\hline Boletus pallidus & 1 & 0 & 1 & 1 & 1 & 1 & 5 \\
\hline Boletus pulverulentus & 0 & 0 & 0 & 0 & 1 & 0 & 1 \\
\hline Boletus sp 1 & 0 & 1 & 0 & 0 & 1 & 0 & 2 \\
\hline Boletus subtomentosus & 0 & 0 & 0 & 0 & 1 & 0 & 1 \\
\hline Cantharellus cibarius & 0 & 0 & 0 & 1 & 1 & 0 & 2 \\
\hline Clavulina sp 1 & 0 & 0 & 1 & 1 & 0 & 0 & 2 \\
\hline Coltricia cinnamomea & 0 & 0 & 0 & 1 & 0 & 0 & 1 \\
\hline Coltricia perennis & 1 & 0 & 1 & 0 & 1 & 0 & 3 \\
\hline Cortinarius alboviolaceus & 0 & 0 & 0 & 0 & 1 & 0 & 1 \\
\hline Cortinarius cf. violaceus & 0 & 0 & 0 & 0 & 1 & 0 & 1 \\
\hline Cortinarius sect. Phlegmacium & 1 & 1 & 0 & 0 & 1 & 0 & 3 \\
\hline Cortinarius rapaceus group & 0 & 0 & 1 & 0 & 0 & 0 & 1 \\
\hline Cortinarius sect. Dermocybe & 0 & 0 & 0 & 0 & 1 & 1 & 2 \\
\hline Cortinarius sp 1 & 0 & 0 & 1 & 0 & 0 & 0 & 1 \\
\hline Cortinarius sp 2 & 0 & 0 & 1 & 0 & 0 & 0 & 1 \\
\hline Cortinarius sp 3 & 0 & 0 & 0 & 0 & 1 & 1 & 2 \\
\hline Cortinarius sp 4 & 0 & 0 & 0 & 0 & 1 & 0 & 1 \\
\hline Cortinarius sect. Telamonia & 1 & 1 & 1 & 1 & 1 & 1 & 6 \\
\hline Craterellus fallax & 0 & 0 & 0 & 1 & 1 & 0 & 2 \\
\hline Elaphomyces sp 1 & 0 & 0 & 0 & 1 & 1 & 0 & $\overline{2}$ \\
\hline Entoloma abortivum & 0 & 0 & 1 & 0 & 0 & 0 & 1 \\
\hline Entoloma cf. griseus & 1 & 1 & 0 & 1 & 1 & 1 & 5 \\
\hline Entoloma $\mathrm{cf}$. sinuatum & 0 & 0 & 0 & 0 & 1 & 1 & 2 \\
\hline Entoloma cf. strictius & 1 & 1 & 1 & 1 & 0 & 1 & 5 \\
\hline Entoloma $\mathrm{sp} 1$ & 0 & 0 & 1 & 0 & 0 & 0 & 1 \\
\hline Entoloma sp 2 & 0 & 0 & 1 & 0 & 0 & 0 & 1 \\
\hline Entoloma sp 3 & 0 & 0 & 0 & 1 & 1 & 0 & 2 \\
\hline Gyroporus castaneus & 0 & 0 & 0 & 0 & 1 & 0 & 1 \\
\hline Gyroporus cyanescens & 0 & 0 & 1 & 1 & 0 & 0 & 2 \\
\hline Hebeloma cf. testaceum & 0 & 0 & 1 & 0 & 0 & 0 & 1 \\
\hline Hebeloma mesophaeum group & 0 & 0 & 1 & 0 & 0 & 0 & 1 \\
\hline
\end{tabular}


DICKIE ET AL: ECTOMYCORRHIZAS OF SAVANNA, FOREST

TABle IV. Continued

\begin{tabular}{|c|c|c|c|c|c|c|c|}
\hline \multirow[b]{2}{*}{ Species } & \multicolumn{3}{|c|}{ Savannas } & \multicolumn{3}{|c|}{ Forests } & \multirow{2}{*}{$\begin{array}{c}\text { Number of } \\
\text { sites }\end{array}$} \\
\hline & 103 & 104 & 106 & 109 & 110 & 309 & \\
\hline Hebeloma sinapizans & 0 & 1 & 0 & 1 & 0 & 0 & 2 \\
\hline Hebeloma $\operatorname{sp~} 1$ & 0 & 1 & 0 & 0 & 0 & 0 & 1 \\
\hline Hebeloma sp 2 & 0 & 0 & 0 & 0 & 0 & 1 & 1 \\
\hline Helvella crispa & 0 & 0 & 1 & 0 & 0 & 0 & 1 \\
\hline Hydnellum concrescens & 1 & 0 & 1 & 0 & 0 & 0 & 2 \\
\hline Hydnellum velutinum var. spongiosipes & 0 & 0 & 0 & 0 & 1 & 0 & 1 \\
\hline Hygrophorus paludosoides & 0 & 0 & 1 & 1 & 1 & 0 & 3 \\
\hline Hygrophorus russula & 0 & 0 & 0 & 1 & 0 & 0 & 1 \\
\hline Inocybe sp 1 & 1 & 1 & 0 & 1 & 0 & 1 & 4 \\
\hline Laccaria aff. laccata & 0 & 0 & 1 & 0 & 0 & 0 & 1 \\
\hline Laccaria amethystina & 0 & 0 & 0 & 1 & 1 & 1 & 3 \\
\hline Laccaria laccata & 1 & 1 & 1 & 1 & 1 & 1 & 6 \\
\hline Laccaria ochropurpurea & 0 & 0 & 0 & 1 & 1 & 1 & 3 \\
\hline Lactarius argillaceifolius & 0 & 1 & 1 & 0 & 0 & 0 & 2 \\
\hline Lactarius atroviridis & 0 & 0 & 0 & 0 & 1 & 0 & 1 \\
\hline Lactarius camphoratus & 1 & 1 & 1 & 1 & 1 & 1 & 6 \\
\hline Lactarius cf. fuliginosus & 0 & 0 & 1 & 0 & 0 & 0 & 1 \\
\hline Lactarius mutabilis & 0 & 1 & 0 & 0 & 0 & 0 & 1 \\
\hline Lactarius sp 1 & 0 & 0 & 0 & 0 & 1 & 0 & 1 \\
\hline Lactarius sp 6 & 0 & 0 & 0 & 0 & 0 & 1 & 1 \\
\hline Lactarius subserifluus & 0 & 0 & 0 & 1 & 1 & 1 & 3 \\
\hline Lyophyllum cf. decastes & 0 & 0 & 1 & 0 & 0 & 0 & 1 \\
\hline Phellodon confluens & 0 & 0 & 0 & 0 & 1 & 0 & 1 \\
\hline Phellodon niger & 0 & 0 & 0 & 1 & 0 & 0 & 1 \\
\hline Ramaria cf. abietina & 0 & 0 & 0 & 0 & 0 & 1 & 1 \\
\hline Ramaria cf. aurea & 1 & 0 & 1 & 1 & 1 & 0 & 4 \\
\hline Ramaria cf. stricta & 0 & 0 & 0 & 0 & 1 & 1 & 2 \\
\hline Russula aff. amoenolens & 1 & 1 & 1 & 1 & 1 & 1 & 6 \\
\hline Russula brevipes & 1 & 1 & 1 & 0 & 0 & 0 & 3 \\
\hline Russula cf. amygdaloides & 1 & 1 & 0 & 1 & 1 & 1 & 5 \\
\hline Russula cf. appalachiensis & 0 & 0 & 0 & 0 & 1 & 0 & 1 \\
\hline Russula cf. fragilis & 0 & 1 & 0 & 0 & 1 & 1 & 3 \\
\hline Russula cf. macropoda & 0 & 0 & 0 & 0 & 1 & 0 & 1 \\
\hline Russula cf. silvicola & 0 & 0 & 0 & 0 & 1 & 0 & 1 \\
\hline Russula laurocerasi & 1 & 0 & 1 & 0 & 1 & 1 & 4 \\
\hline Russula seperina & 1 & 1 & 1 & 1 & 1 & 1 & 6 \\
\hline Russula sp 1 & 1 & 1 & 1 & 1 & 1 & 1 & 6 \\
\hline Russula variata & 1 & 0 & 1 & 1 & 1 & 0 & 4 \\
\hline Russula xerampelina group & 1 & 0 & 1 & 1 & 1 & 1 & 5 \\
\hline Scleroderma areolatum & 0 & 0 & 0 & 0 & 0 & 1 & 1 \\
\hline Strobilomyces floccopus & 1 & 0 & 1 & 1 & 1 & 1 & 5 \\
\hline Thelephora anthocephala & 0 & 0 & 1 & 0 & 0 & 0 & 1 \\
\hline Thelephora cf. caryophylla & 0 & 1 & 0 & 0 & 0 & 0 & 1 \\
\hline Thelephora terrestris & 0 & 1 & 0 & 0 & 0 & 0 & 1 \\
\hline Tomentella cf. bryophila & 0 & 0 & 1 & 0 & 0 & 0 & 1 \\
\hline Tremellodendron pallidum & 1 & 1 & 1 & 1 & 1 & 0 & 5 \\
\hline Tricholoma cf. flavobrunneum & 1 & 0 & 0 & 0 & 0 & 0 & 1 \\
\hline Tricholoma saponaceum & 0 & 0 & 0 & 0 & 1 & 0 & 1 \\
\hline Tricholoma sejunctum & 0 & 0 & 1 & 1 & 1 & 0 & 3 \\
\hline Tricholoma sulphurescens & 0 & 0 & 0 & 1 & 1 & 0 & 2 \\
\hline Tricholoma venenatum & 0 & 0 & 0 & 1 & 1 & 0 & 2 \\
\hline Total species & 25 & 37 & 47 & 40 & 60 & 31 & \\
\hline
\end{tabular}


cially valuable mushroom in the edible porcini complex was described only recently from oak-pine woods in western New York (Bessette et al 2000) but was probably reported from Minnesota under various incorrect names (e.g. Boletus edulis [Bull.] Fr., B. aestivalis [Paulet] Fr., B. variipes Peck) since at least the late 19th century (Peck 1889). The identity of this species was initially problematic due to incomplete and confusing taxonomic data on this group of mushrooms, but ITS sequences from our collections matched the ITS from the holotype specimen at 100\% identity (Dentinger 2007). Although we have collections of this species from forest habitats near our sites, it was never found in our sampled plots and we only encountered it consistently in open savanna habitats. This pattern reveals the importance of savanna habitat to the maintenance of fungal diversity. In addition to highlighting the need for conserving savanna habitats the great abundance of B. nobilissimus in oak savanna after periods of warm weather $(\geq 33 \mathrm{C}$ ) and heavy rains (Dentinger pers obs) illustrates the potential for making conservation of savanna a profitable endeavor through sustainable development of non-timber forest products such as edible mushrooms. Similarly certain truffles (Hydnotrya, Pachyphloeus) appear to be mainly savanna species. Hypogeous fungi typically go unnoticed but their conservation might depend on savanna preservation.

The fungal community overall was highly diverse but is consistent with other studies of mixed-hostspecies communities (Dickie 2007, Ishida et al 2007). Despite being the more "natural" state of these ecosystems, oak savannas were not more diverse than oak forests. Nonetheless oak savanna might play an important role in supporting regional diversity because some ectomycorrhizal species were savanna specialists, while other species were restricted to forests. Maintaining a heterogeneous mixture of habitats therefore will result in the highest across-site diversity of ectomycorrhizal fungi.

\section{ACKNOWLEDGMENTS}

Kirk Haskins initiated this experiment, including initial sporocarp surveys and location of sample plots. We thank Susan Barrott, Cindy Buschena, Holly Swanson and Camille Jensen for help with both field and laboratory work. Financial support was provided by the US National Science Foundation Long Term Ecological Research program (NSF/DEB 0080382), a grant from the Graduate School, University of Minnesota, and the Minnesota Agricultural Experiment Station. IAD also was supported by the Foundation for Research, Science and Technology (FRST) of New Zealand during the analysis and writing stage of this research.

\section{LITERATURE CITED}

Avis PG, McLaughlin DJ, Dentinger BC, Reich PB. 2003. Long-term increase in nitrogen supply alters above- and belowground ectomycorrhizal communities and increases the dominance of Russula spp. in temperate oak savanna. New Phytol 160:239-253.

—, Mueller GM, Lussenhop J. 2008. Ectomycorrhizal fungal communities in two North American oak forests respond to nitrogen addition. New Phytol 179:472-483.

Bergemann SE, Garbelotto M. 2006. High diversity of fungi recovered from the roots of mature tanoak (Lithocarpus densiflorus) in northern California. Can J Bot 84: 1380-1394.

Bessette A, Roody W, Bessette A. 2000. North American Boletes: a color guide to the fleshy pored mushrooms. Syracuse, New York: Syracuse Univ. Press. 396 p.

Bills GF, Holtzman GI, Miller Jr OK. 1986. Comparison of ectomycorrhizal-basidiomycete communities in red spruce versus northern hardwood forests of West Virginia. Can J Bot 64:760-768.

Bray JR. 1960. The composition of savanna vegetation in Wisconsin. Ecology 41:721-732.

Bruns T, Tan J, Bidartondo M, Szaro T, Redecker D. 2002. Survival of Suillus pungens and Amanita francheti ectomycorrhizal genets was rare or absent after a stand-replacing wildfire. New Phytol 155:517-523.

Dahlberg A, Jonsson L, Nylund JE. 1997. Species diversity and distribution of biomass above and below ground among ectomycorrhizal fungi in an old-growth Norway spruce forest in south Sweden. Can J Bot 75:1323-1335.

Dentinger B. 2007. Systematics and evolution of porcini and clavarioid mushrooms [Doctoral dissertation]. University of Minnesota.

Dickie IA. 2007. Host preference, niches and fungal diversity. New Phytol 174:230-233.

- Avis PG, McLaughlin DJ, Reich PB. 2003. Goodenough RFLP matcher (GERM) program. Mycorrhiza 13:171-172.

— Guza RC, Krazewski SE, Reich PB. 2004. Shared ectomycorrhizal fungi between a herbaceous perennial (Helianthemum bicknellii) and oak (Quercus) seedlings. New Phytol 164:375-382.

, Reich PB. 2005. Ectomycorrhizal fungal communities at forest edges. J Ecol 93:244-255.

— - Xu W, Koide RT. 2002. Vertical niche differentiation of ectomycorrhizal hyphae in soils as shown by TRFLP analysis. New Phytol 156:527-535.

Egger KN. 1986. Substrate hydrolysis patterns of post-fire ascomycetes (Pezizales). Mycologia 78:771-780.

Fujimura KF, Smith JE, Horton TR, Weber NS, Spatafora JW. 2005. Pezizalean mycorrhizas and sporocarps in ponderosa pine (Pinus ponderosa) after prescribed fires in eastern Oregon, USA. Mycorrhiza 15:79-86.

Gebhardt S, Neubert K, Wöllecke J, Münzenberger B, Hüttl RF. 2007. Ectomycorrhiza communities of red oak (Quercus rubra L.) of different age in the Lusatian lignite mining district, east Germany. Mycorrhiza 17: 279-290.

Gehring CA, Theiner TC, Whitham TG, Keim P. 1998. 
Ectomycorrhizal fungal community structure of pinyon pines growing in two environmental extremes. Ecology 79:1562-1572.

Genney DR, Anderson IC, Alexander IJ. 2006. Fine-scale distribution of pine ectomycorrhizas and their extramatrical mycelium. New Phytol 170:381-390.

Grundel R, Pavlovic N. 2007. Distinctiveness, use and value of Midwestern oak savannas and woodlands as avian habitats. The Auk 124:969-985.

Hall IR, Brown GT, Zambonelli A. 2008. Taming the truffle: the history, lore and science of the ultimate mushroom. Portland, Oregon: Timber Press. 304 p.

Ishida TA, Nara K, Hogetsu T. 2007. Host effects on ectomycorrhizal fungal communities: insight from eight host species in mixed conifer-broadleaf forests. New Phytol 174:430-440.

Last FT, Mason PA, Ingleby K, Fleming LV. 1984. Succession of fruitbodies of sheathing mycorrhizal fungi associated with Betula pendula. For Ecol Manage 9:229-234.

Lilleskov EA, Fahey TJ, Horton TR, Lovett GM. 2002. Belowground ectomycorrhizal fungal community change over a nitrogen deposition gradient in Alaska. Ecology 83:104-115.

McGill BJ, Etienne RS, Gray JS, Alonso D, Anderson MJ, Benecha HK, Dornelas M, Enquist BJ, Green JL, He F, et al. 2007. Species abundance distributions: moving beyond single prediction theories to integration within an ecological framework. Ecol Lett 10:995-1015.

Nuzzo VA. 1985. Extent and status of Midwest oak savanna: presettlement and 1985. Nat Areas J 6:6-36.

Oksanen J, Kindt R, Legendre P, O'Hara B, Simpson GL, Stevens M. 2008. vegan: community ecology package. $R$ package version 1.11-2. http://vegan.r-forge.r-project. org/

Peay KG, Bruns TD, Kennedy PG, Bergemann SE, Garbelotto M. 2007. A strong species-area relationship for eukaryotic soil microbes: island size matters for ectomycorrhizal fungi. Ecol Lett 10:470-480.

Peck C. 1889. Boleti of the United States. Bull New York State Mus 2:73-166.

Peterson DW, Reich PB. 2001. Prescribed fire in oak savanna: fire frequency effects on stand structure and dynamics. Ecol Applic 11:914-927.

R Development Core Team. 2008. R: a language and environment for statistical computing. Version 2.6.2. Vienna, Austria: R Foundation for Statistical Computing.

Reich PB, Peterson DW, Wedin DA, Wrage K. 2001. Fire and vegetation effects on productivity and nitrogen cycling across a forest-grassland continuum. Ecology 82:17031719.

Richard F, Millot S, Gardes M, Selosse MA. 2005. Diversity and specificity of ectomycorrhizal fungi retrieved from an old-growth Mediterranean forest dominated by Quercus ilex. New Phytol 166.

Siemann E, Haarstad J, Tilman D. 1997. Short-term and long-term effects of burning on oak savanna arthropods. Am Mid Nat 137:349-361.

Smith ME, Douhan GW, Rizzo DM. 2007. Ectomycorrhizal community structure in a xeric Quercus woodland based on rDNA sequence analysis of sporocarps and pooled roots. New Phytol 174:847-863.

- Trappe JM, Rizzo DM. 2006. Genea, Genbea and Gilkeya gen. nov.: ascomata and ectomycorrhiza formation in a Quercus woodland. Mycologia 98:699-716.

Taylor AFS. 2002. Fungal diversity in ectomycorrhizal communities: sampling effort and species detection. Pl Soil 244:19-28.

Taylor DL, Bruns TD. 1999. Community structure of ectomycorrhizal fungi in a Pinus muricata forest: minimal overlap between the mature forest and resistant propagule communities. Mol Ecol 8:18371850.

Tedersoo L, Suvi T, Jairus T, Kõljalg U. 2008. Forest microsite effects on community composition of ectomycorrhizal fungi on seedlings of Picea abies and Betula pendula. Environ Microbiol 10:1189-1201.

— - L Larsson E, Kõljalg U. 2006. Diversity and community structure of ectomycorrhizal fungi in a wooded meadow. Mycol Res 110:734-748.

Tester JR. 1996. Effects of fire frequency on plant species in oak savanna in east-central Minnesota. Bull Torrey Bot Club 123:304-308.

Valentine LL, Fieldler TL, Hart AA, Petersen CA, Berninghausen HK, Southworth D. 2004. Diversity of ectomycorrhizas associated with Quercus garryana in southern Oregon. Can J Bot 82:123-135.

Vrålstad T, Holst-Jensen A, Schumacher T. 1998. The postfire discomycete Geophyxis carbonaria (Ascomycota) is a biotrophic root associate with Norway spruce (Picea abies) in nature. Mol Ecol 7:609-616.

Walker JF, Miller Jr OK, Horton JL. 2005. Hyperdiversity of ectomycorrhizal fungus assemblages on oak seedlings in mixed forests in the southern Appalachian Mountains. Mol Ecol 14:829-838.

Warcup JH. 1991. The fungi forming mycorrhizas on eucalypt seedlings in regeneration coupes in Tasmania, Australia. Mycol Res 95:329-332.

White AS. 1983. The effects of thirteen years of annual prescribed burning on a Quercus ellipsoidalis community in Minnesota. Ecology 64:1081-1085.

Zhou ZH, Hogetsu T. 2002. Subterranean community structure of ectomycorrhizal fungi under Suillus grevillei sporocarps in a Larix kaempferi forest. New Phytol 154:529-539. 